(Fakul tas Kesehatan Universi tas Muhammadiyah Gresik)

\title{
Pemberdayaan Keluarga Rawan Pangan Melalui Penguatan Aspek Kognitif Dan Psikomotor Sebagai Upaya Peningkatan Pemenuhan Kebutuhan Nutrisi Balita Di Wilayah Kerja Puskesmas Mulyorejo Surabaya
}

\author{
Eka Mishbahatul Mar'ah Has'), Elida Ulfiana ${ }^{2)}$, Setho Hadisuyatmana ${ }^{3)}$, Dwi Faqihatus S. Has ${ }^{4)}$ \\ ${ }^{1,2,3)}$ Departemen Keperawatan Jiwa dan Komunitas, Fakultas Keperawatan, Universitas Airlangga Surabaya \\ Kampus C Universitas Airlangga, Kecamatan Muyorejo, Kota Surabaya, Jawa Timur \\ 4) Program Studi Gizi , Fakultas Kesehatan , Universitas Muhammadiyah Gresik \\ Jl. Proklamasi No.54 Gresik, Kecamatan Gresik, Kabupaten Gresik, Jawa Timur \\ e-mail correspondence : eka.m.has@fkp.unair.ac.id
}

\begin{abstract}
Abstrak
Malnutrisi masih menjadi masalah gizi utama anak di Indonesia. Malnutrisi dan rawan pangan hampir tidak dapat dipisahkan. Rawan pangan didefinisikan sebagai suatu kondisi ketidakmampuan untuk memperoleh pangan yang cukup dan sesuai untuk hidup sehat. Tujuan kegiatan pengabdian masyarakat ini adalah penguatan kemampuan kognitif dan psikomotor keluarga rawan pangan dalam memenuhi kebutuhan nutrisi balita di wilayah kerja Puskesmas Mulyorejo, Kecamatan Mulyorejo, Kota Surabaya. Metode pendekatan yang akan dilakukan dalam kegiatan pengabdian masyarakat ini adalah memberikan informasi dan ketrampilan yang sederhana, murah dan mudah untuk diaplikasikan oleh ibu dari keluarga rawan pangan dalam memenuhi kebutuhan nutrisi balitanya. Pelaksanaan kegiatan pengabdian masyarakat akan dilakukan secara bertahap, meliputi: 1)Pendidikan kesehatan melalui tatap muka dan diskusi, 2)Pelatihan pemilihan bahan, pengolahan, dan penyajian makanan bergizi untuk balita, serta 3). Monitoring dan evaluasi. Evaluasi dilaksanakan di awal, proses, dan akhir kegiatan dengan cara berikut: 1) Pre-test: diberikan kuesioner untuk di jawab oleh peserta, 2) Proses: dilakukan saat pelatihan; ceramah, diskusi, demonstrasi berdasarkan respon dan keaktifan peserta serta Post-test: diberikan kuesioner setelah selesai mengikuti pelatihan. Dari hasil evaluasi kegiatan masyarakat didapatkan hasil peningkatan kemampuan kognitif dan psikomotor dengan rata rata $75 \%$. Hasil evaluasi ini membuktikan bahwa kegiatan pengabdian masyarakat ini berhasil dan sesuai dengan target.
\end{abstract}

Kata kunci: Pemberdayaan, Keluarga Rawan Pangan, Peningkatan Kognitif dan Psikomotor

\section{Abstract}

Malnutrition still became nutritional problem of children in Indonesia. Malnutrition and food insecurity are hardly separable food insecure is defined as condition of inability to acquire adequate and suitable food for a healthy. The purpose of this community's dedication is to strengthen the cognitive and psychomotor skills flood-prone families in meeting the nutritional needs of children in Mulyorejo, Surabaya City. The method that will be done in this community's dedication activities is to provide information and skills (simple, inexpensive, and easy) to apply by the mother (flood-prone) families in fulfilling the nutritional-needs. The implementation public service activities will be carried out gradually, including 1) health education and discussion, 2) training, processing, and serving nutritious food for toddlers 3). Monev. Evaluation is carried out at beginning, process, and activities in the following ways: 1) Pretest: Given the questionnaire and answered by participant, 2) process: conducted during training; lectures, discussions, demonstrations based on the response and activity of participants and Posttest: Given the questionnaire after completion of the training. The results of the evaluation public activities obtained 
the results increased cognitive and psychomotor skills with an average $75 \%$. The results proved that the community's dedication activities were successful and accordance with target.

\section{Key words:. Empowerment, family-prone food, cognitive enhancement and psychomotor}

\section{PENDAHULUAN}

Malnutrisi masih menjadi masalah gizi utama anak di Indonesia ${ }^{[1]}$. Malnutrisi digunakan untuk menggambarkan kondisi gizi yang salah, yang memiliki rentang dari gizi buruk sampai gizi lebih. Malnutrisi terutama terjadi setelah anak melewati usia 6 bulan. Sampai 6 bulan pertama kehidupan, pertumbuhan dan perkembangan bayi relatif sama [2], selanjutnya situasi lingkungan terutama asupan zat gizi dan infeksi turut berkontribusi ${ }^{[3]}$.

Malnutrisi dan rawan pangan hampir tidak dapat dipisahkan ${ }^{[4]}$. Rawan pangan didefinisikan sebagai suatu kondisi ketidakmampuan untuk memperoleh pangan yang cukup dan sesuai untuk hidup sehat dan beraktivitas dengan baik utnuk sementara waktu dalam jangka panjang. Rawan pangan tidak hanya mengandung unsur yang berhubungan dengan state of poverty saja seperti masalah kelangkaan sumber daya alam, kekurangan, modal, miskin motivasi, dan sifat malas juga menyebabkan ketidakmampuan keluarga mencukupi konsumsi pangan. Sementara, keluarga rawan pangan adalah keluarga yang tingkat konsumsi energinya ratarata $71-89 \%$ dari kecukupan energi normal ${ }^{[5]}$.

Banyaknya keluarga rawan pangan masih terjadi di semua propinsi dengan besaran yang berbeda. Berdasarkan data SUSENAS 2006, proporsi penduduk rawan pangan di semua propinsi masih di atas $10 \%$ kecuali di propinsi Sumbar, Bali dan NTB. Jumlah anak balita dengan status gizi buruk dan gizi kurang di daerah rawan pangan juga masih tinggi. Kondisi ini menunjukkan bahwa ketahanan pangan di tingkat nasional atau wilayah tidak selalu berarti bahwa tingkat ketahanan pangan di rumah tangga dan individu juga terpenuhi. Masalah-masalah distribusi dan mekanisme pasar yang berpengaruh pada harga, daya beli rumah tangga yang berkaitan dengan kemiskinan dan pendapatan rumah tangga, dan tingkat pengetahuan tentang pangan dan gizi sangat berpengaruh pada konsumsi dan kecukupan pangan dan gizi rumah tangga ${ }^{[6]}$.

Rawan pangan (food insecurity) merupakan kondisi dimana keluarga mengalami kesulitan didalam memenuhi kebutuhan pangan. Menurut Sri Sumarmirawan pangan dapat dikelompokkan kedalam keadaan kronis (chronical food insecurity) dan sementara (transitory food insecurity).Rawan pangan kronis merupakan kondisi kurang pangan (untuk tingkat rumah tangga berarti kepemilikan pangan lebih sedikit dari pada kebutuhan dan untuk tingkat individu konsumsi pangan lebih rendah dari kebutuhan biologis) yang terjadi sepanjang waktu.Sedangkan pengertian rawan pangan 
sementara mencakup rawan pangan musiman (seasonal). Rawan pangan ini dapat terjadi karena adanya kejutan (shock) yang mendadak dan tak terduga seperti kekeringan dan ledakan serangan hamayang sangat membatasi kepemilikan pangan oleh rumah tangga, terutama mereka yang berada di pedesaan.Bagi rumah tangga di perkotaan rawan pangan tersebut dapat disebabkan antara lain oleh pemutusan hubungan kerja ${ }^{[7]}$.

Balita belum mampu memenuhi kebutuhan gizi secara mandiri, sehingga masih tergantung pada orang dewasa yang ada di lingkungan sosial terdekatnya, yaitu keluarga ${ }^{[7]}$.Pada mayoritas keluarga, ibu berperan penting dalam pengaturan makan anggota keluarga ${ }^{[8]}$. Perilaku ibu yang meliputi pengetahuan, sikap, dan tindakan menentukan dalam pemilihan bahan makanan bergizi, serta menyusun menu seimbang sesuai kebutuhan dan selera keluarga, sehingga pemenuhan kebutuhan gizi balita tergantung pada perilaku ibu ${ }^{[9]}$. Perilaku ibu dalam pemenuhan kebutuhan gizi berpengaruh terhadap status gizi anak balita ${ }^{[10]}$.

Rumusan masalah kegiatan pengabdian masyarakat ini adalah untuk mengetahui Apakah kemampuan ibu keluarga rawan pangan dalam pemenuhan kebutuhan nutrisi balita dapat ditingkatkan melalui pemberdayaan dengan penguatan aspek kognitif dan psikomotornya. Tujuan kegiatan pengabdian masyarakat ini adalah penguatan kemampuan kognitif dan psikomotor keluarga rawan pangan dalam memenuhi kebutuhan nutrisi balita di wilayah kerja Puskesmas Mulyorejo, Kecamatan Mulyorejo, Kota Surabaya.

Oleh karena itu, perlu adanya pemberdayaan ibu yang berasal dari keluarga rawan pangan melalui penguatan aspek kognitif dan psikomotor sebagai upaya peningkatan pemenuhan kebutuhan nutrisi balita.

\section{METODE}

2.1. Khalayak Sasaran

Kegiatan ini dilakukan dengan melibatkan 12 keluarga rawan pangan di wilayah puskesmas Mulyorejo

2.2. Lokasi dan Waktu Kegiatan

Puskesmas Mulyorejo, Kecamatan Mulyorejo, Kota Surabaya. Dilaksanakan pada bulan februari 2020.

\subsection{Rancangan Kegiatan}

Metode pendekatan yang akan dilakukan dalam kegiatan pengabdian masyarakat ini adalah memberikan informasi dan ketrampilan yang sederhana, murah dan mudah untuk diaplikasikan oleh ibu dari keluarga rawan pangan dalam memenuhi kebutuhan nutrisi balitanya. Teknologi informasi yang ingin ditawarkan untuk mengatasi masalah nutrisi yang sering terjadi pada keluarga rawan pangan adalah dengan melakukan pendidikan kesehatan untuk menguatkan pemahaman mereka mengenai penyediaan gizi murah, sehat, dan sesuai dengan kebutuhan gizi balita. Selain itu juga tepat bahan, tepat pengolahan, dan kreatif dalam penyajian. Metode pendidikan kesehatan yang digunakan bukan 
hanya ceramah, tetapi juga demonstrasi dan simulasi. Media penyampaian teknologi juga disiapkan, yaitu berupa modul dan alat peraga.

Pelaksanaan kegiatan pengabdian masyarakat akan dilakukan secara bertahap, meliputi:

1) Pendidikan kesehatan melalui tatap muka dan diskusi.

2) Pelatihan pemilihan bahan, pengolahan, dan penyajian makanan bergizi untuk balita.

3) Monitoring dan evaluasi.

Kegiatan pengabdian masyarakat ini dilakukan pada ibu yang berasal dari keluarga rawan pangan, yang memiliki balita, yang tercatat sebagai penduduk di wilayah kerja Puskesmas Mulyorejo, Kecamatan Mulyorejo, Kota Surabaya. Mitra kegiatan adalah Puskesmas Mulyorejo. Keterlibatan mitra adalah melalui penyediaan sarana dan prasarana untuk pelaksanaan kegiatan. Harapan selanjutnya dari kegiatan ini adalah menurunkan angka gizi kurang dan buruk balita di wilayah kerja Puskesmas Mulyorejo, sampai 0\%, terutama dari keluarga rawan pangan.

Materi yang diberikan pada kegiatan penyuluhan:
1) Konsep gizi
2) Kecukupan gizi balita
3) Pola nutrisi balita
4) Pemilihan bahan, pengolahan, dan penyajian makanan bergizi untuk balita.

Evaluasi dilaksanakan di awal, proses, dan akhir kegiatan dengan cara berikut:

1) Pre test : diberikan kuesioner untuk di jawab oleh peserta

2) Proses : dilakukan saat pelatihan; ceramah, diskusi, demonstrasi berdasarkan respon dan keaktifan peserta

3) Post test : diberikan kuesioner setelah selesai mengikuti pelatihan

\section{HASIL DAN PEMBAHASAN}

Kegiatan ini dilakukan dengan melibatkan 12 keluarga rawan pangan di wilayah puskesmas Mulyorejo. Hasil evaluasi dari kegiatan ini adalah terdapat kenaikan aspek kognitif dan psikomotor pada keluarga rawan pangan yakni $75 \%$ atau 0,75. Berikut ini adalah hasil perubahan aspek kognitif dan psikomotor pada keluarga rawan pangan pada tabel 1:

Tabel 1: perubahan aspek kognitif dan psikomotor

\begin{tabular}{|l|r|r|r|}
\hline Responden (Inisial) & Pre & \multicolumn{1}{|l|}{ Post } & \multicolumn{1}{l|}{ Gain } \\
\hline LLK & 2 & 6 & 4 \\
\hline BSR & 6 & 6 & 0 \\
\hline Sprh & 6 & 6 & 0 \\
\hline FA & 9 & 0 & -9 \\
\hline LS & 2 & 5 & 3 \\
\hline RAN & 3 & 6 & 3 \\
\hline DA & 6 & 9 & 3 \\
\hline SJ & 4 & 6 & 2 \\
\hline SL & 4 & 7 & 0 \\
\hline EY & 5 & 3 & -1 \\
\hline EA & 0 & 2 & -3 \\
\hline LF & & 7 & 7 \\
\hline
\end{tabular}

Sumber: Data Primer 
Pada Tabel diatas dapat dilihat bahwa kegiatan pengabdian masyarakat ini telah berhasil sesuai dengan target, yakni ada peningkatan pada penguatan kemampuan kognitif dan psikomotor keluarga rawan pangan dalam memenuhi kebutuhan nutrisi balita di wilayah kerja Puskesmas Mulyorejo, Kecamatan Mulyorejo, Kota Surabaya.

Hasil pengabdian masyarakat ini sejalan dengan hasil penelitian (Yuniriyanti, 2016) yang menyatakan bahwa pemberdayaan keluarga rawan pangan dapat melalui ibu ibu rumah tangga yang tergabung dalam PKK desa dan Dasa Wisma sebagai pelaku dan pengelola pekarangan, sebagai penggerak peningkatan nutrisi balita di Desa. Selama ini PKK sudah begitu melembaga baik di tingkat pusat, propinsi, kabupaten, kecamatan maupun desa. PKK dengan berbagai kegiatannya dalam pelaksanaannya telah merambah hingga tingkat dusun, RT dan Dasa wisma adalah kelompok ibu-ibu berasal dari 1020 rumah yang bertetangga. Kelompok Dasa Wisma adalah kelompok yang terdiri dari 10 -20 kepala keluarga (KK) dalam satu RT. Setelah terbentuk kelompok, maka diangkatlah satu orang yang memiliki tanggung jawab sebagai ketua. Tujuan kelompok Dasa Wisma ini adalah membantu kelancaran tugas-tugas pokok dan program PKK kelurahan. Dasa Wisma sebagai salah satu wadah kegiatan masyarakat memiliki peran yang sangat penting dalam pelaksanaan program-program kegiatan gerakan PKK di tingkat desa, yang nantinya akan berpengaruh pula pada kegiatan gerakan PKK di tingkat Kecamatan dan Kabupaten ${ }^{[11]}$.

\section{KESIMPULAN}

1. Keberhasilan kegiatan pengabdian masyarakat penguatan kemampuan kognitif dan psikomotor keluarga rawan pangan dalam memenuhi kebutuhan nutrisi balita di wilayah kerja Puskesmas Mulyorejo, Kecamatan Mulyorejo, Kota Surabaya dapat terwujud karena adanya kerjasama mitra, lintas sektor dan masyarakat

2. Peningkatan kemampuan kognitif dan psikomotor keluarga rawan pangan dalam memenuhi kebutuhan nutrisi balita di wilayah kerja Puskesmas Mulyorejo, Kecamatan Mulyorejo, Kota Surabaya adalah sebesar $75 \%$.

3. Keterlibatan mitra sangat membantu dalam pelaksanaan kegiatan melalui penyediaan sarana dan prasarana untuk pelaksanaan kegiatan.

\section{SARAN}

1. Harapan selanjutnya dari kegiatan ini adalah menurunkan angka gizi kurang dan buruk balita di wilayah kerja Puskesmas Mulyorejo, sampai $0 \%$, terutama dari keluarga rawan pangan

2. Diharapkan pemberdayaan keluarga rawan pangan juga dapat melalui ibu ibu rumah tangga yang tergabung dalam PKK desa dan Dasa Wisma sebagai pelaku dan pengelola 
pekarangan, sebagai penggerak peningkatan

nutrisi balita di Desa

\section{DAFTAR PUSTAKA}

[1] E. Nasution, "USU Digital Library," 14 Januari $2004 . \quad$ [Online]. Available: www.repository.usu.ac.id/bitstream/123456789/368 8/1/fkm-ernawati.pdf. [Accessed 6 Januari 2012].

[2] B. Boggin, Patterns of Human Growth Edition, 2nd Edition, Cambrige: Cambrige University Press, 1999.

[3] A. Syafiq, "Tinjauan Atas Kesehatan dan Gizi Anak Usia Dini," Mercy Corp, Jakarta, 2008.

[4] T. Budiarti, P. Wahjurini and F. Suryawati, "Hubungan antara asupan gizi dengan tumbuh kembang anak usia 5-6 tahun," Jurnal Penelitian Kesehatan Suara Forikes, pp. 44-50, 2011.

[5] UNICEF, "State of World Children," UNICEF, New York, 2006.

[6] C. Vereecken, W. Van Damme and L. Maes, "Measuring attitudes, self efficacy, and social and environmental influences on fruit and vegetable consumption of 11- and 12-year-old children: reliability and validity," Journal of The American Dietetic Association, pp. 257-261, 2005.

[7] J. Gregory, S. Paxton and A. Brozovic, "Maternal feeding practice, child eating behavior and body mass index in preschool-aged children: a prospective analysis," International Journal of Behavioral Nutrition and Physical Activity, pp. 110, 2010.

[8] T. Masithah, Soekirman and D. Martianto, "Hubungan pola asuh makan dan kesehatan dengan status gizi anak batita di desa mulya harja," Media gizi dan keluarga, pp. 29-39, 2005.

[9] L. D. Popularita, "Hubungan pengetahuan, sikap, tindakan, dan pola asuh ibu dengan status gizi balita usia 1-5 tahun.Skripsi," Universitas Airlangga (tidak dipublikasikan), Surabaya, 2010.

[10 V. Dawis, "PELAKSANAAN DAN MANFAAT

] KEGIATAN PEMBERDAYAAN MASYARAKAT RAWAN PANGAN DI DKI JAKARTA," SEPA, pp. 88-96, 2013.

[11 E. Yuniriyanti, "MODEL PEMBERDAYAAN

] WANITA DALAM UPAYA PENINGKATAN KETAHANAN PANGAN KELUARGA MELALUI KELOMPOK DASA WISMA PKK," Universitas Negeri Malang, Malang, 2016. 